\title{
WARNING LABEL AND VIDEO EFFICACY ON HIGH SCHOOL STUDENT CONSUMPTION OF SOFT DRINK AND FAST FOOD
}

\author{
Ujang Sumarwan $^{1 *}$, Siti Atilah ${ }^{2}$, Vici Lucyta Lestari ${ }^{3}$ \\ ${ }^{1,2,3}$ Department of Family and Consumer Sciences, Faculty of Human Ecology, IPB \\ University, Bogor, 16680, Indonesia
}

*Corresponding author: sumarwan@apps.ipb.ac.id

\begin{abstract}
Excessive consumption of fast food and soft drink causes various negative impacts on health. This study aims to analyze the knowledge and intention toward fast food and soft drinks consumption on adolescents. The design used in this study was preexperimental in one of senior high schools in Bogor Regency. Samples of this study 96 students and chosen by convinience. Samples are divided into three groups, which are warning the label exposure group, the video exposure group, and the control group. Research results show that warning label and video are able to increase knowledge of fast food and soft drinks. In addition, the exposure of the warning label and video also reduced the intention of the sample in consuming fast food and soft drinks. The results of one way ANOVA test showed that the knowledge and intention of the control group differed significantly with the experimental group both with the exposure of warning labels and video. Further testing results of the Post Hoc Test showed that warning label exposure further enhance knowledge than video exposure and without exposure. Warning labels and video effectively reduce the intention to consume fast food and soft drinks.
\end{abstract}

Keywords: experiments, fast food, intention, knowledge, soft drink

\begin{abstract}
Abstrak
Fast food dan soft drink adalah bagian dari kehidupan manusia saat ini yang sangat sulit untuk dilepaskan. Konsumsi fast food dan soft drink secara berlebihan dapat menyebabkan berbagai dampak negatif pada kesehatan, baik pada orang dewasa maupun remaja. Penelitian ini bertujuan menganalisis pengetahuan dan intensi konsumsi fast food dan soft drink pada remaja. Desain yang digunakan adalah preeksperimental di salah satu SMA Kabupaten Bogor. Contoh penelitian berjumlah 96 siswa dipilih secara convinience dan dibagi menjadi tiga kelompok, yaitu kelompok warning label, kelompok video, dan kelompok kontrol. Hasil penelitian menunjukkan bahwa pemaparan warning label dan video mampu meningkatkan pengetahuan remaja mengenai dampak negatif darifast food dan soft drink. Sebaliknya, paparan warning label dan video dapat menurunkan intensi remaja dalam mengonsumsi fast food dan soft drink. Selain itu, hasil uji one way ANOVA menunjukan bahwa pada pengetahuan dan intensi remaja yang dipaparkan warning label dan video berbeda secara signifikan dengan yang tidak diberikan paparan. Adapun, hasil uji lanjut Post Hoc Test menunjukkan paparan warning label lebih meningkatkan pengetahuan remaja daripada video dan tanpa paparan. Penelitian ini juga menemukan warning label dan video efektif menurunkan intensi konsumsi remaja terhadap fast food dan soft drink.

Kata kunci: eksperimen, fast food, intensi, pengetahuan, soft drink
\end{abstract}




\section{Introduction}

Along with the times and technology, the food and beverage industry has also undergone changes that have an impact on people's consumption behavior. The most felt shift in food consumption that was initially traditional to modern food, including fast food and soft drinks. Fast food is an oily and sodium-rich food, which can cause obesity, increase cholesterol, lead to diabetes, stroke and heart attacks (Chen \& Huang, 2013). Meanwhile, Safriani (2014) explains that soft drinks are beverages that do not contain alcohol and in form of powder or liquid containing food ingredients and other additives. Additional materials used are from natural or synthetic ingredients which are packaged instantly. The increase in the consumption of fast food in Indonesia can be seen from the number of fast food restaurants.

The survey conducted by MasterCard in 2011 saw Consumer Purchasing Priorities mention that 71 percent of Asians, including Indonesians, prefer fast food restaurants. The increase in soft drink consumption can be seen from the number of its production industries that increase annually. The number of medium and large-scale soft drink industries was 422 industries in 2015, this number increases from the previous year which was only 374 industries (BPS, 2016). The average age of group who consume fast food and soft drinks are teenage groups. Powell and Nguyen (2013) stated teenagers tend to like to eat outdoors, especially in fast food restaurants. Rafiony et al. (2015) surveyed consumer behavior in teenager of high school students in Pontianak City, Indonesia. The survey results shows that 60 percent of teens often visit fast food restaurants every weekend and 44 percent of teens consume soft drinks. Consumption research conducted by Spire Research and Consulting in collaboration with Marketing Magazine in 2008 of 1000 teenager respondents aged 13-18 in major cities in Indonesia found that teens consumed as many as two bottles or cans of soft drinks a week (Skriptiana, 2009).

Most teenager consider eating behavior to be part of their lifestyle which causes of adolescents having unbalanced eating behavior, including skipping breakfast and consuming fast food and soft drinks (French et al., 2001). The shifts in eating habits into the consumption of fast food and soft drinks have a negative impact. Fast food tends to have a high energy content, deficient in micronutrients, low in fiber, high in glycemic load and excessive in portion size. This causes the excess daily energy needed by someone (Rosenheck, 2008). Research conducted on adolescents and children shows that excessive consumption of fast food causes obesity (Rosenheck, 2008; Payab et al., 2015). Other studies also support that consumption of fast food is related to weight gain and low nutritional status (Boutelle et al., 2007; Powell \& Nguyen, 2013). Also, consumption of fast food has an impact on puberty in young women, Kustin et al. (2017) states that the high use of fast food impacted the emergence of early adolescence in young women. Similarly with fast food consumption, consuming soft drinks in excess also has a negative impact on drinkers. Ramdhani (2010) explains that consuming soft drinks regularly and excessively can cause a severe effect on drinkers. Soft drinks which contain sugar substitute is associated with an increase in the number of obesity, diabetes, cavities, bone loss (osteoporosis), and low levels of nutrients.

Seeing from the hazards of fast food and soft drinks, it is necessary to make efforts to reduce consumption in the community especially teenagers. Given that teenagers are the next generation of the nation who will become leaders in the country. 
Prospective leaders should get clear and accurate information about a product that is consumed daily to create qualified human resources. Information about the risk of consuming fast food and soft drinks also becomes very important for teenagers to be considered and be wise in absorbing their primary needs. This information can be conveyed through various types of communication media, including print and audiovisual media (video).

According to Health and Consumer Protection (2006), warning labels or information can be useful to provide information about the risk of consuming a product to consumers. Some previous studies have discussed a lot about consumption of fast food and soft drinks. However, most studies examine the effects caused by fast food. This study discusses the behavior of adolescents in consuming fast food and soft drinks, namely by measuring teenagers' consumption knowledge and intentions on fast food and soft drinks. Knowledge and intention are closely related to one's behavior. Someone decided to consume or not a product if they know the benefits and impacts of the products consumed (Sumarwan, 2011). The intention is a desire, will, willingness, and plan to carry out certain behaviors (Wildyana \& Suyasa, 2006). If someone has an intention to do an action, then the greater chance a person will do it.

Based on the explanation, the objectives of this study were: (1) to identify the knowledge and intentions in consumption of fast food and soft drinks in the experimental and the control group; (2) to analyze the differences in knowledge and intention of consumption in fast food and soft drinks before and after treatment in the experimental and the control group; (3) to analyze the differences in knowledge and intention in consumption of fast food and soft drinks between groups.

\section{Method}

This study used the classical experiment method with the pre-experimental design because randomization was not carried out in sampling for each group. The sampling method of this study was convenience non-probability sampling with 96 students of class XI in one of the Public High Schools in Bogor Regency, Indonesia. Location determination is done purposively. The location was chosen based on the consideration that schools have canteens and stalls that sell various types of soft drinks and also around the school location there are minimarkets and supermarkets that sell soft drinks. Besides, around the school location, various fast food restaurants sell fast food.

The experimental method in this study used an experimental laboratory form because the samples were in the room and did the controlling to independent variables of the study. The laboratory experiment method is intended to test the teenager's knowledge and intentions in the consumption of fast food and soft drinks based on the exposure that had given.

This research was conducted by dividing the sample into three groups which were carried out in three different rooms for each group, namely the warning label group (32 people) and the video group (32 people), while the control group (32 people) were not given any exposure. After being divided into three groups, then the sample is given a pre-test questionnaire to measure knowledge and intentions. After processing the pretest sample, we are welcome to take a break in the room first for five minutes followed by filling in the post-test questionnaire of knowledge and intention. After a five minute break, firstly the experimental group was given exposure to the warning label, and video, then filled out the post-test questionnaire. 
The type of data used in this study are primary data since its obtained from questionnaires made by the author. The filling out of the questionnaire was filled out by samples directly which included the characteristics of the samples (age, sex, and allowance per day), knowledge of fast food and soft drinks, and the intention to consume fast food and soft drinks. Fast food knowledge instruments use thirteen questions with the choice of the right answer (1) or wrong (0) with Cronbach's alpha value of 0.715 and soft drink knowledge is measured using twelve statements with Cronbach's alpha value of 0.505 . Intention instruments for fast food consumption were measured using eight items of questions assessed using a Likert scale strongly disagree (1), disagree (2), less agree (3), agree (4), and strongly agree (5) with the value of Cronbach's alpha amounting to 0.876 , while the measurement of the intention to consume soft drinks uses ten statements with the value of Cronbach's alpha 0.864 .

The categorization of knowledge variables refers to the cut-off of Khomsan et al. (2009) which consists of less or lower (60.0-79.0), medium (60.0-79.0), and excellent or high (80.0-100.0). Intention is categorized into three categories: low, medium, and high. The intention category refers to the cut-off class interval from (Maehara \& Yuliati, 2013). The maximum value of fast food consumption intention is 40 , and the minimum amount is 8. Intention categorized as low if the index score is lower than 18.67, classified medium if the index score is in the range of 18.67 to 29.34 , and classified as high if the index score is higher than 29.34. The maximum value of the soft drink consumption intention is 50 , and the minimum is 10 . The soft drink consumption intention is categorized using the class interval formula, namely low $(<23.33)$, medium (23.33-36.66), and high (> 36.66).

Data were analyzed using descriptive analysis and inferential analysis using Microsoft Excel 2010 and Statistical Package for Social Science (SPSS) version 22.0 for Windows. The descriptive study which includes frequency, the maximum, minimum, average is used to identify the characteristics of samples, knowledge, and intention to consume fast food and soft drinks for samples. The inferential analysis used a paired-sample t-test to see the differences in knowledge and intentions before and after treatment and the One Way ANOVA to test the gaps in knowledge and intention between groups.

\section{Findings}

\section{Respondent Characteristics}

The study shows almost two-thirds $(62.5 \%)$ of the samples were female with an average age of 16.6 years old. In each experimental group, samples generally had 17 years of age, 68.8 percent in the warning label group, 50.0 percent in the video group, and 56.3 percent in the control group. The minimum sample allowance is IDR 5.000, and the highest is IDR 50.000. In each group, the sample allowance is at most in the range of IDR $10.001-20.000$ per day, 50.0 percent in the warning label group and 62.5 percent in the video group and the control group.

\section{Knowledge}

The knowledge measured in this study is a knowledge of the samples regarding the content and adverse effects of fast food and soft drinks. The control group knows the material and adverse impact of fast food in almost the same proportion in each category 
in the pre-test, while in the post-test more than two-fifths $(40.6 \%)$ of the samples are in the excellent class. In the warning label of the experimental group, more than half $(59.4 \%)$ of the samples'pre-test was in a good category, while in the post-test it increased to $(78.1 \%)$ the samples of knowledge are in a good category. Half $(50.0 \%)$ of the samples in the video group had knowledge at the pre-test in the good category, while in the post-test more than half the sample $(62.5 \%)$ had knowledge in the good category.

Regarding knowledge about soft drinks, the results of the study showed that less than half $(40.6 \%)$ of the sample of experimental group warned that labels had knowledge of consumption in both the pre-test category. More than five-sixths $(84.4 \%)$ samples have good category knowledge after being given treatment for exposure warning (post-test). In the experimental video group, less than half (43.8\%) of the samples had good knowledge before the treatment (pre-test) and less than two-thirds $(62.5 \%)$ samples had good knowledge after being given video exposure (post-test). Less than half $(40.6 \%)$ of the samples in the control group had sufficient knowledge at the pre-test and post-test.

\section{Differences in Knowledge Before and After Treatment}

Based on the results of different tests in Table 1, it can be seen that on fast food consumption, groups with exposure label warnings have significant knowledge differences between before and after exposure $(\alpha=0.05)$. The average value of the knowledge index in the group with exposure to the warning label is 80.7 then increases to 87.3 after being given exposure. The increase in the average value of knowledge variables can be seen from the increase in the value of each item question given in the sample, namely in the statement "fast food is a food that does not cause addiction", "fast food has good nutritional content", "fast food is a qualified and health food", "fast food contains high levels of micronutrients ", and "fast food does not use a lot of oil in the cooking process." Unlike the results in the warning label exposure group, there is no difference between the control and video group. However, in Table 1 it is known that there is an increase in the average value between the pre-test and post-test in the control group with the delta score 3.4 and the video exposure group with the delta score 7.2.

Table 1 The differences in knowledge of fast food and soft drinks before and after being given treatment

\begin{tabular}{lccrr}
\hline \multicolumn{1}{c}{ Group } & Pre-test & Post-test & \multirow{2}{*}{ Delta score } & \multirow{2}{*}{ Sig. } \\
\cline { 2 - 3 } Fast Food Knowledge & Mean & Mean & & \\
\hline Warning label group & 80.7 & 87.3 & +6.6 & $0.018^{* *}$ \\
Video group & 73.8 & 81.0 & +7.2 & $0.095^{*}$ \\
Control group & 69.7 & 73.1 & +3.4 & 0.275 \\
\hline Soft Drink Knowledge & & & +14.8 & $0.000 * * *$ \\
\hline Warning label group & 72.7 & 87.5 & +6.5 & $0.002 * * *$ \\
Video group & 75.0 & 81.5 & +2.1 & 0.485 \\
Control group & 71.1 & 73.2 &
\end{tabular}

Table 1 shows that the samples have given exposure to the warning label and video has a significant difference in knowledge between before treatment and after treatment. Knowledge of samples is higher after being given exposure to the warning label and video compared to before being given exposure. The increased knowledge in 
the label warning group can be seen from the increase in the average answer of the samples in the statement of "soft drinks contain carbohydrates", "consuming soda will cause dehydration in the body", "consuming soft drinks once a day will not have a negative effect on health ", and" consuming soft drinks in excess can cause asthma." In the video group, the average increase is in the statement "consuming soda will cause dehydration in the body," "soft drinks contain carbohydrates," and "consuming soft drinks in excess can cause asthma." There were no significant differences in knowledge between the pre-test and post-test in the control group. The samples group given exposure to the warning label had the highest average increase compared to the group given video exposure and the control group with the delta score before and after the treatment of 14.8 .

\section{Intention}

The intention measured in this study is the sample's intention in consuming fast food and soft drinks. The results show that in the pre-test control group, three-quarters $(75.0 \%)$ of the samples had consumption intentions of fast food in the medium category and one-fourth $(25.0 \%)$ of the samples were included in the low category. In the posttest, almost three-quarters $(71.9 \%)$ of the samples had medium-term intentions, onefourth $(25.0 \%)$ of the samples were in a low category, and the rest $(3.1 \%)$ were in the high category.

In the pre-test of the experimental group warning label, more than three-fifths $(68.7 \%)$ had intentions in the medium category, almost one-third $(31.3 \%)$ of the samples had low-category intentions. In the post-test, more than three-fifths $(65.6 \%)$ of the samples had intentions in the medium category, and the rest (34.4\%) had lowcategory intentions.

In the pre-test of the experimental video group, more than three-fifths $(65.6 \%)$ of the samples had medium category intentions, less than one-third (31.3\%) of the samples had low category intentions and the rest $(3.1 \%)$ were in the high category. In the posttest, almost three-fifths (59.4\%) had low category intentions, and more than two-fifths $(40.6 \%)$ of the samples were in the medium category.

The results also show that in the experimental group's warning label, more than half $(56.3 \%)$ of the samples had medium consumption of soft drink consumption intention, 40.6 percent in the low category, and only 3.1 percent in the high category in the pre-test. In the post-test, more than half $(53.1 \%)$ of the samples had consumption intentions in the low category and less than half (46.9) samples of the medium category.

More than three-quarters $(78.1 \%)$ of the sample video experimental group had medium soft drink consumption intentions, and the rest $(21.9 \%)$ were low when they were given video exposure. More than half $(53.1 \%)$ of the samples had the intention of consuming soft drinks in the low category and the rest (46.9\%) in the medium category after being given exposure (post-test).

In the control group, more than half $(56.3 \%)$ of the samples had medium category intentions, less than half $(40.6 \%)$ in the low category, and the rest $(3.1 \%)$ in the high category during the pre-test. Less than two-thirds $(62.5 \%)$ of samples have a medium category, and the rest (37.5\%) have low category intentions in the post-test. 


\section{Differences in Intention Before and After Treatment}

Data from Table 2 shows the level of intention to consume fast food and soft drinks in three different groups. The results showed that on fast food consumption there were no significant differences between pre-test and post-test in the control group. In groups with exposure to the label warning, it can be seen that there is a very significant difference in intention between pre-test and post-test with a value of $\alpha=0.01$. The average intention of the label warning group before exposed was 37.0 and then decreased to 27.0 after exposure. The video group also showed similar things because there were very significant changes in the intention of the sample at the pre-test and post-test $(\alpha=0.01)$. The common intention in the video group before being given exposure was 37.9 then decreased to 27.6 after being given exposure. These changes can be clearly seen in the statement item "I will continue to consume fast food in the future", "I will buy fast food in the next week", "I intend to increase consumption of fast food", "I would say positive about fast food to others", and"when I eat, I will prioritize eating fast food." The decrease in intention shows that the desire for samples in fast food is lower after being given exposure, both warning labels, and videos.

Table 2 also shows that in soft drink consumption there is a significant difference between the intention of consumption of soft drinks before and after treatment in the group given exposure to warning labels and videos. The intention of consumption of samples is lower after being given treatment than before treatment. The decrease in soft drink consumption intention in the label warning group can be seen from the decrease in the average answer of the example in the statement "will continue to consume soft drinks in the future", "will consume soft drinks in the next week", "intending to increase consumption of soft drinks", "will not reduce consumption of soft drinks", and"will prioritize the consumption of soft drinks when I am thirsty afterdoing activities or hot weather". Video groups, almost all statement items have decreased on average except in the statement "will consume soft drinks in the next three days" and "intend to increase consumption of soft drinks". There were no significant differences in intention between pre-test and post-test in the control group. The highest reduction in consumption intention occurred in the group given video exposure with a delta score before and after the treatment of 10.5 .

Table 2 Differences in the intention of consuming fast food and soft drinks before and after treatment

\begin{tabular}{lcccr}
\hline \multirow{2}{*}{ Group } & Pre-test & Post-test & \multirow{2}{*}{ Delta Score } & \multirow{2}{*}{ Sig. } \\
\cline { 2 - 3 } & Mean & Mean & & \\
\cline { 1 - 2 } Consumption Intention Fast Food & & & & \\
Warning label group & 40.1 & 32.5 & -7.6 & $\mathbf{0 . 0 0 0} * *$ \\
Video group & 39.5 & 33.2 & -6.3 & $\mathbf{0 . 0 0 2 * *}$ \\
Control group & 45.3 & 44.3 & -1 & 0.511 \\
\hline Consumption Intention Soft drink & 39.8 & 32.0 & -7.8 & $\mathbf{0 . 0 0 0 * * *}$ \\
Warning label group & 42.9 & 32.4 & -10.5 & $\mathbf{0 . 0 0 0 * * *}$ \\
Video group & 43.2 & 39.8 & -3.4 & 0.303 \\
Control group & Notes: *significant at $\mathrm{p}<0.1 ; * *$ significant at $\mathrm{p}<0.05 ; * * *$ significant at $\mathrm{p}<0.01$ &
\end{tabular}




\section{Differences in Knowledge and Intention Between Groups Before and After Treatment}

Different tests between groups were carried out using a variant difference test or ANOVA, because it aimed to see differences in more than two groups, namely the exposure label warning group, the video group, and the control group. ANOVA tests for the pre-test showed there was no significant differences between the three treatment groups both on fast food and soft drink consumption (Table 3). Different results were obtained at post-test or after exposure. Table 3 shows that at fast food there are very significant differences in the knowledge and intention variables between the three groups with a value of $\alpha=0.01$. In consuming soft drinks, there are significant differences between the three treatment groups in the knowledge variable. However, the results show that there was no significant differences between the three exposure groups in the intention variable. In consuming soft drinks, there was no significant difference in knowledge and intention to consume soft drinks between treatment groups when before being given treatment. However, there were significant differences in knowledge between groups after being given treatment ( $\mathrm{sig}=0.000$ ). The results of the ANOVA test also showed that there was no significant differences $(\operatorname{sig}=0.129)$ between groups after being given treatment (Table 3 ).

Table 3 The ANOVA test results of knowledge and intention after treatment

\begin{tabular}{lcccc}
\hline \multirow{2}{*}{ Variables } & \multicolumn{2}{c}{ Fast food } & \multicolumn{2}{c}{ Soft drink } \\
\cline { 2 - 5 } & $\mathrm{F}$ & Sig. & $\mathrm{F}$ & Sig. \\
\hline Before treatment & & & & \\
Knowledge & 2.489 & 0.088 & 0.520 & 0.596 \\
Intention & 0.997 & 0.373 & 0.435 & 0.649 \\
\hline After treatment & & & & \\
Knowledge & 6.120 & $0.003 * *$ & 9.204 & $0.000^{* * *}$ \\
Intention & 10.064 & $0.000^{* *}$ & 2.095 & 0.129 \\
\hline Notes: *significant at $\mathrm{p}<0.1 ; * *$ significant at $\mathrm{p}<0.05 ; * * *$ significant at $\mathrm{p}<0.01$ & \multicolumn{3}{l}{}
\end{tabular}

The post hoc test results in Table 4 present the differences in each variable between groups with exposure label, video, and control warnings. In fast food consumption, there was a significant difference in the knowledge variable between the warning label group and the control group at $\alpha=0.01$. The control group also differed significantly from the experimental group for video exposure but with a value of $\alpha=0.1$. Besides, the test results do not show a significant difference between the warning label group and the video group. This shows that exposure to warning labels and video exposure do not differ significantly in changing the sample's knowledge. The intention variable also shows the difference between the control and experimental groups both on exposure to the label and video warnings at the real level of $99 \%$.

On the other hand, there was no significant difference between the experimental group exposure to warning labels and videos. These results indicate that exposure to label and video warnings can cause a very significant difference in intention (sig = 0.000) compared to the control and there were no significant differences between the two groups. Furthermore, the results of the Post Hoc Test continued showed that there were significant differences in knowledge and intention of soft drink consumption between each group. 
There was a significant knowledge difference between the experimental warning label group, the video group, and the control group. The sample's knowledge in the warning label group was higher compared to the video group $(\operatorname{sig}=0.07$ ) and the control group ( $\mathrm{sig}=0.000$ ), and knowledge of the sample video group was higher than the control group ( $\operatorname{sig}=0.015)$. There was a significant difference between the motivation of the experimental warning label group, and the motivation of the control group (0.058), the motivation of the warning label group was lower than the control group. The sample's motivation for the video group had a significant difference with the control group ( $\mathrm{sig}=0.095$ ). The motivation for consumption of the video group was lower than the control group. The test results also showed a significant difference between the intention of the warning label group and the control group ( $\mathrm{sig}=0.073$ ) and the video group with the control group ( $\mathrm{sig}=0.088$ ). The intention of the label and video group warning groups was lower than the intention of the control group (Table 4).

Table 4 Post Hoc Test of knowledge and intention among groups after treatment

\begin{tabular}{lllrrrr}
\hline Variables & (I)Treatment & (J)Treatment & \multicolumn{2}{c}{ Fast food } & \multicolumn{2}{c}{ Soft drink } \\
\cline { 4 - 7 } & & & Delta (I-J) & Sig. & \multicolumn{1}{c}{ Delta (I- } & Sig. \\
\hline Knowledge & Warning label & Video & 6.250 & 0.127 & 5.989 & $0.077^{*}$ \\
& Warning label & Control & $14.182^{*}$ & $0.001^{* *}$ & 14.322 & $0.000^{* * *}$ \\
& Video & Control & 7.932 & $0.054^{*}$ & 8.333 & $0.015^{* * *}$ \\
\hline Intention & Warning label & Video & -.585 & 0.893 & -.390 & 0.928 \\
& Warning label & Control & $-17.187^{*}$ & $0.000^{* *}$ & -7.812 & $0.073^{*}$ \\
& Video & Control & $16.601^{*}$ & $0.000^{* *}$ & -7.421 & $0.088^{*}$ \\
\hline
\end{tabular}

Notes: *significant at $\mathrm{p}<0.1 ; * *$ significant at $\mathrm{p}<0.05 ; * * *$ significant at $\mathrm{p}<0.01$

\section{Discussions}

Fast food is a fast, easy-to-access, and preferred food for people of all age groups. Fast food is usually served in large portions and contains high energy, sugar, and salt, and low micronutrient and fiber content (Majabadi et al., 2016). Based on the results of the study found that more than four-five samples $(83.0 \%)$ at least consume fast food one to three times a week. This figure looks low, but according to research by Mahdiah et al. (2004) in adolescents in Yogyakarta, Indonesia shows that consuming fast food more than four times per month tends to cause obesity. Other results show that more than half $(60.4 \%)$ of samples consume fast food in restaurants that provide fast food and more than two-fifths $(41.7 \%)$ of them eating with friends.

Consumption of fast food is usually accompanied by the consumption of soft drinks. Soft drinks are beverages that do not contain alcohol, powder or liquid form containing food ingredients (Cahyadi, 2008). The results showed that the frequency of soft drink consumption for samples was less than once a week consumption (47.9\%), two to four times a week consumption (37.5\%), and five or more than five times a week (14.6\%). According to Tania (2016) consuming soft drinks less than or once a week is categorized as low, twice to four times a week is categorized as medium, and five to six times a week or every day categorized as high.

Adolescents who consume soft drinks regularly have high and low calcium energy intake, which can increase obesity (Whitney \& Rolfes, 2005). The reason for the consumption of soft drinks, the most expressed is because it tastes good and refreshes. Soft drinks have a sweet and refreshing taste, especially when served in cold conditions 
that make teens love it. This is because soft drinks have a high sugar content, which creates comfort and happiness after drinking it (Suragimath et al., 2009). Stalls or minimarkets are places that are often visited by adolescents to buy soft drinks because stalls or supermarkets sell soft drinks and are located in their sphere.

Knowledge is all information that consumers have about various kinds of products and services and other related to these products and services and information linked to functions as consumers (Sumarwan, 2011). Test results with paired sample t-test showed that in the control group, there was no significant difference in knowledge between the pre-test and post-test. Different things are shown in the exposure group of label warnings which show that exposure ofwarning label is proven to cause a very significant change of knowledge in both fast food and soft drinks. The sample's knowledge tends to increase after exposure due to an increase in the average value. These results are in accordance with research by Hankin et al. (1993) who found that giving a warning label to alcoholic beverages can increase knowledge for those who read it. The results in the video exposure group showed significant knowledge differences in both fast food and soft drinks. The results of this study are in line with the research of Wicaksono (2016) and Kapti et al. (2013) who found that video media was effective in increasing the knowledge of mothers and children under two and five years old.

According to Fishbein and Ajzen (1975) intention is the strength of a person performing certain behaviors and the closest determinant to behavior and is the best single predictor of behavior to be carried out. The results showed that the intention to consume fast food and soft drinks samples decreased after getting exposure to warning labels and videos. The results of this study are in line with the research of Suyasa and Shanti (2015) who found that the warning label on packaging fosters an intention to stop smoking by 81 percent and will stop smoking. The same thing was expressed by Brewer et al. (2016) which states that the warning label increases the intention of someone to stop consuming products. This is reinforced by the research by Bushman (1998) who found that people who were given exposure to warning labels tended not to consume products that had the warning label. The results of this study are also in line with the research conducted by Sumathy and Nithyakalyani (2017) which shows that exposure to video media can reduce the desire to consume soft drinks.

The ultimate goal of the warning label is to provide information on the product and protect consumers from possible dangers of using a product (White \& Parsons, 2001). Thewarning label does have the purpose of providing information, in other words, to increase knowledge for those who read it. Added by Spink et al. (2011), warnings on the label are intended to prevent accidents such as injury, illness, or property damage. It is assumed that if given appropriate warnings of hazards, consumers tend to reduce doing something harmful.

The results of research by Glock et al. (2013) show that the warning labels placed on alcohol products can make consumers have negative attitudes and reduce the intention to consume them. Based on this explanation, the warning label is intended to increase knowledge and change unhealthy lifestyle also show that the warning label can increase knowledge and reduce the attitude and intention of samples in fast food consumption. The video is a media that plays an important role since it is one of the most powerful and expressive non-textual media in conveying information (Hampapur et al., 1995). The results of the study suggest that the video gives a very significant change in the attitude and intention of the samples. After being given video exposure, 
the attitude of the samples tends to be more negative and consumption intention decreases.

\section{Conclusion and Recommendation}

\section{Conclusion}

Teenagers' knowledge of the negative impact in consuming fast food and soft drinks has been categorized both during pre-test and post-test and there has been an increase in the number of adolescents who have been given exposure to warning labels and videos compared to adolescents who were not given intervention. In addition, teenagers' intention to consume fast food and soft drinks was generally categorized as being in the pre-test and post-test period, but there was an increase in the number of adolescents in the low category after being given the warning label and video presentation. Increased adolescent knowledge about the negative impact of consuming fast food and soft drinks is higher when given exposure to warning labels compared to video exposure and not given exposure. Also, teenagers' desire or intention to consume fast food and soft drinks will decrease when they get exposure to warning labels compared to videos.

\section{Recommendation}

Consumption of unhealthy foods and beverages such as fast food and soft drinks should be reduced given the adverse effects on health. Teenagers should be wiser in consuming a product and start choosing a healthy one. Family and school have an important role in providing education to adolescents. The things that can be done by the family are to provide an explanation of the benefits and effects of consuming a product and pay attention to the food and drinks consumed by teenagers. Schools can provide education as consumers who are wise in their conduct, in this case, consumption behavior. In addition, the government should begin to appeal to the public, especially the younger generation, to adopt healthy food consumption and not consume fast food and soft drinks. Judging from the results of research, the government can apply the use of warning labels on fast food packaging. The government can also make public service advertisements displayed on television to be seen by many people.

\section{References}

Boutelle, K. N., Fulkerson, J. A., Neumark-Sztainer, D., Story, M., \& French, S. A. (2007). Fast food for family meals: relationships with parent and adolescent food intake, home food availability and weight status. Public health nutrition, 10(1), 16-23.

[BPS] Badan Pusat Statistik. (2016). Jumlah Perusahaan Industri Besar Sedang Menurut Sub Sektor (2 digit KBLI), 2000-2015. Jakarta (ID): BPS.

Brewer, N. T., Hall, M. G., Noar, S. M., Parada, H., Seroussi., Bach, L. E., Hanley, S., Ribisy, K. M. (2016). Effect of pictorial cigarette pack warnings on changes in smoking behavior a randomized clinical trial. JAMA Intern Med. 176(7), 905912.doi:10.1001/jamainternmed.2016.2621.

Bushman, B. J. (1998). Effects of warning and information labels on consumption of full-fat, reduced-fat, and no-fat products. Journal of Applied Psychology, 83(1), 97. 
Cahyadi, S. (2008). Analisis dan Aspek Kesehatan Bahan Tambahan Pangan. Cetakan Kedua. Jakarta (ID): PT. Bumi Aksara.

Chen, M. F., Huang, C. H. (2013). The impacts of the food traceability system and consumer involvement on consumers' purchase intentions toward fast foods. Food Control, 33(2), 313-319.

French, S. A., Story, M., Neumark-Sztainer, D., Fulkerson, J. A., Hannan, P. (2001). Fast food restaurant use among adolescents: associations with nutrient intake, food choices and behavioral and psychosocial variables. International journal of obesity, 25(12), 1823.

Fishbein, M., Ajzen, I. (1975). Beliefs, Attitude, Intention and Behavior: an Introduction to Theory and Research. Philippines: Addison-Wesley Publishing.

Glock, S., Müller, B. C., Ritter, S. M. (2013). Warning labels formulated as questions positively influence smoking-related risk perception. Journal of health psychology, 18(2), 252-262.

Hampapur, A., Jain, R., Weymouth, T. (1995). Production model based digital video segmentation. Journal of Multimedia Tools and Applications 1: 9-46.

Hankin, J. R., Sloan, J. J., Firestone, I. J., Ager, J. W., Sokol, R. J., Martier, S. S., Townsend, J. (1993). The alcohol beverage warning label: When did knowledge increase?. Alcoholism: Clinical and Experimental Research, 17(2), 428-430.

Health and Consumer Protection. (2006). Labelling: competitiveness, consumer information and better regulation for the EU. European Commission.

Kapti, R. E., Rustina, Y., Widyatuti, W. (2013). Efektifitas audiovisual sebagai media penyuluhan kesehatan terhadap peningkatan pengetahuan dan sikap ibu dalam tatalaksana balita dengan diare di dua rumah sakit kota Malang. Jurnal Ilmu Keperawatan, 1(1), 53-60.

Khomsan, A., Anwar, F., \& Mudjajanto, E. S. (2009). Pengetahuan, sikap, dan praktek gizi ibu peserta Posyandu. Jurnal Gizi dan Pangan,4(1), 3341.DOI: http://dx.doi.org/10.25182/jgp.2009.4.1.33-41.

Kustin, K., Wahyuningtyias, F., Munawir, A. (2017). The effects of junk food consumption on incidence of early puberty in adolescent females. Health Notions, 1(4), 408-413.

Mahdiah, M., Hadi, H., Susetyowati, S. (2004). Prevalensi obesitas dan hubungan konsumsi fast food dengan kejadian obesitas pada remaja SLTP kota dan desa di Daerah Istimewa Yogyakarta. Jurnal Gizi Klinik Indonesia, 1(2), 69-77.

Majabadi, H. A., Solhi, M., Montazeri, A., Shojaeizadeh, D., Nejat, S., Farahani, F. K., \& Djazayeri, A. (2016). Factors influencing fast-food consumption among adolescents in tehran: a qualitative study. Iranian Red Crescent Medical Journal, 18(3).

Maehara, D., Yuliati, L. N. (2013). Alokasi waktu, motivasi, kendala, dan niat berwirausaha pada isteri nelayan. Jurnal Ilmu Keluarga \& Konsumen, 6(1), 49-57. DOI: http://dx.doi.org/10.24156/jikk.2013.6.1.49.

Payab, M., Kelishadi, R., Qorbani, M., Motlagh, M. E., Ranjbar, S. H., Ardalan, G., Heshmat, R. (2015). Association of junk food consumption with high blood pressure and obesity in Iranian children and adolescents: the CASPIAN-IV Study. Jornal de pediatria, 91(2), 196-205.

Powell, L. M., Nguyen, B. T. (2013). Fast-food and full-service restaurant consumption among children and adolescents: effect on energy, beverage, and nutrient intake. JAMA pediatrics, 167(1), 14-20. 
Rafiony, A., Purba, M. B., Pramantara, I. D. P. (2015). Konsumsi fast food dan soft drink sebagai faktor risiko obesitas pada remaja. Jurnal Gizi Klinik Indonesia, 11(4), 170-178.

Ramdhani, A. (2010). Women's Health. Bandung (ID): Leaf Production.

Rosenheck, R. (2008). Fast food consumption and increased caloric intake: a systematic review of a trajectory towards weight gain and obesity risk. Obesity Reviews, 9(6), 535-547.

Safriani, F. (2014). Faktor-faktor yang berhubungan dengan perilaku konsumsi minuman ringan (soft drink) pada siswa SMA di Bogor [Skripsi]. Bogor (ID): Institut Pertanian Bogor.

Skriptiana, N. R. (2009). Hubungan antara pengetahuan gizi, pengaruh teman sebaya, pengaruh media massa dan faktor lain dengan konsumsi minuman ringan berkarbonasi pada siswa-siswi SMPIT Nurul Fikri tahun 2009[skripsi]. Depok (ID): FKM UI.

Spink, J., Singh, J., Singh, S. P. (2011). Review of package warning labels and their effect on consumer behaviour with insights to future anticounterfeit strategy of label and communication systems. Packaging Technology and Science, 24(8), 469-484.

Sumarwan, U. (2011). Peilaku konsumen: Teori dan Penerapannya dalam Pemasaran. $2^{\text {th }}$ ed. Bogor (ID): Penerbit Ghalia Indonesia.

Sumathy, P, Nithyakalyani, P. (2017). Effectiveness of video assisted teaching programme on knowledge and practice regarding junk food and its effects among adolescents in selected urban school at Puducherry. International Journal of Applied Research, 3(6), 574-577.

Suragimath, G., Krishnaprasad, K. R., Moogla, S., Sridhara, S. U., Raju, S. (2010). Effect of carbonated drink on excisional palatal wound healing: A study on Wistar rats. Indian Journal of Dental Research, 21(3), 330.

Suyasa, I. N. G., Shanti, D. G. D. D. (2015). Efektifitas tulisan dan gambar peringatan kesehatan pada produk rokok terhadap kesadaran merokok di Kabupaten Bandung, Bali- 2015. Intisari sains medis 9(1), 19-24. doi:10.1556/ism.v9i1.148.

Tania, M. (2016). Hubungan pengetahuan remaja dengan perilaku konsumsi minuman ringan di SMKN 2 Baleendah Bandung. Jurnal ilmu keperawatan. 7 (1), 19-25.

White, E, Parsons, A. L. (2001). Comprehension of warnings and resulting attitudes. Journal of Consumer Affairs, 35(2), 278-294.

Whitney, E., Rolfes, S. R.(2005). Understanding Nutrition. 10th ed. United States (US) : Peter Marshall.

Wicaksono, D. (2016). Pengaruh media audio-visual MP-ASI terhadap pengetahuan, sikap, dan perilaku ibu baduta di PU puskesmas Kelurahan Johar Baru. Jurnal Penelitian dan Pengabdian. 4 (2), 291-298. doi.org/10.29313/ethos.v0i0.1974.g1215.

Wildyana, Suyasa, P.T.Y.S. (2006). Persepsi terhadap kemasan dan Intensi Membeli. Jurnal Ilmiah Psikologi Industri dan Organisasi, 8(2), 110-124. 